Seminário de Pesquisa

Programa de Pós-Graduação

Design FAU USP

\title{
Coleta e análise de dados dos métodos na prática de projetos de design para espaços no contexto pandêmico do ensino superior brasileiro
}

\author{
Thábata Regina de Souza Brito, Cibele Haddad Taralli
}

design para espaços; métodos; práticas de projetos; ensino superior

\section{Curso}

Doutorado

\section{Linha de Pesquisa}

Design: Processos e Linguagens

\section{Thábata Regina de Souza Brito}

Doutoranda em Design pela

Universidade de São Paulo.

Mestra em Design, Inovação e

Sustentabilidade pela Universidade do Estado de Minas Gerais - UEMG

e Designer de Ambientes também pela UEMG. Professora no Centro Universitário UNA. Lecionou na UEMG e no Instituto Federal de Minas Gerais.

e-mail: thabatabrito@usp.br Lattes: http://lattes.cnpq. br/1738067592058379

\section{Cibele Haddad Taralli}

Professor Sênior e docente do PPGDESIGN da FAUUSP nas seguintes áreas de pesquisa e abordagens: arquitetura; design do produto; design social e de serviços; design e ensino; design centrado no usuário/humano; design, ambiente e espaços; processos e procedimentos de pesquisa e design.

e-mail: cibelet@usp.br

Lattes: http://lattes.cnpq. $\mathrm{br} / 6016190566941978$

Orcid: https://orcid.org/00000002-5330-0387
A pesquisa intenciona identificar a origem, as características, as especificidades e os caminhos adotados nos métodos utilizados nas práticas de projetos de design voltado para a criação de espaços. A investigação se desenvolve com base em levantamento do referencial teórico, com entrevista semi estruturada, questionários e posteriormente pesquisa in loco em cursos universitários tecnológicos e bacharelados selecionados em design de interiores e/ou em design de ambientes para fundamentar o estudo através das perspectivas dos professores, alunos e coordenadores de curso.Esta é uma pesquisa qualitativa, na modalidade de estudo de reconhecimento, a respeito de concepções mais comumente endossadas e adotadas sobre o método na prática de projeto especificamente ensinado e utilizado na academia do campo do design para espaços, também chamado de Design de Interiores e Design de Ambientes. O referencial teórico utilizou-se da fundamentação filosófica da fenomenologia para caracterizar tanto o fenômeno do design, quanto o campo do design que propõem a formulação e reformulação dos espaços, o entendimento da relação entre ambiente, sujeito e artefatos. No contexto pandêmico no qual estamos vivendo, a utilização do levantamento de dados pelo referencial teórico se dá de forma virtual, assim como os questionários que estão sendo aplicados a alunos de três instituições do ensino superior na região metropolitana de Belo Horizonte MG e as entrevistas semiestruturada que estão sendo feitas com professores e coordenadores de curso dessas três academias. Em um segundo momento, propõe-se visitar essas instituições, assim como, outra universidade em um diferente estado brasileiro para confrontar e ou validar os dados. 


\title{
Collection and data analysis of methods in the practice of design projects for spaces in the pandemic context of Brazilian higher education
}

\author{
Thábata Regina de Souza Brito, Cibele Haddad Taralli
}

design for spaces; methods; project practices; higher education

The research intends to identify the origin, characteristics, specificities and paths adopted in methods used in the practices of design projects aimed at the creation of spaces. The investigation is developed based on a survey of the theoretical framework, with semi-structured interviews, questionnaires and "in loco" field research to be developed posteriorly in technological university courses and bachelor's degrees in interior design and / or in environmental design selected in order to base the study through the perspectives of teachers, students and course coordinators. This is a qualitative research, in the form of a study of recognition about the most commonly endorsed and adopted concepts about the method in the practice of design specifically taught and used in the academy in the field of spatial design, also called Interior Design and Environment Design. The theoretical framework used the philosophical foundation of phenomenology to characterize

\section{Course}

Doctoral

\section{Line of Research}

Design: Processes and Languages

Thábata Regina de Souza Brito

PhD student in Design at the University of São Paulo. Master in Design, Innovation and Sustainability from the State University of Minas Gerais - UEMG and Designer of Environments also from UEMG. Professor at University Center UNA. She taught at UEMG and at the Federal Institute of Minas Gerais.

e-mail: thabatabrito@usp.br

Lattes: http://lattes.cnpq. br/1738067592058379

\section{Cibele Haddad Taralli}

Senior Professor and professor at FAUUSP's PPGDESIGN in the following research areas and approaches: architecture; product design; social and service design; design and teaching; human/usercentered design; design, spaces, and environment; research and design processes and procedures. e-mail: cibelet@usp.br

Lattes: http://lattes.cnpq. $\mathrm{br} / 6016190566941978$

Orcid: https://orcid.org/00000002-5330-0387 both the design phenomenon and the design field that propose the formulation and reformulation of spaces, the understanding of the relationship between environment, human beings and artifacts. In the pandemic context in which we are living, the use of data collection by the theoretical framework takes place virtually, as well as the questionnaires that are being applied to students from three higher education institutions in the metropolitan region of Belo Horizonte - MG and semi-structured interviews being conducted with teachers and course coordinators from these three academies. In a second step, it is proposed to visit these institutions, as well as another university in a different Brazilian state to confront and or validate the data. 